\title{
Study of hyper bilirubinemia in Low Birth Weight (LBW) and Normal Birth Weight (NBW) babies
}

\author{
V VV N S. Ravi Sankar'1, Reddy L. N², Vijayalakshmi B ${ }^{3}$, Sravanthi N. L ${ }^{4}$ \\ ${ }^{1}$ Dr. V V V N S Ravi Sankar, $3^{\text {rd }}$ Year PG, NRI Medical College, ${ }^{2}$ Dr. Notu Linga Reddy, Assistant Professor, NRI \\ Medical College, ${ }^{3}$ Dr. Bhimireddy Vijayalakshmi, Professor, NRI Medical College, ${ }^{4}$ Dr. Nalluru Lakshmi Sravanthi, \\ Associate Professor, All authors are affiliated with, Department of Pediatrics, NRI Medical College, Chinakakani, \\ Mangalagiri, Guntur, Andhra Pradesh, India.
}

Corresponding Author: Dr. Notu Linga Reddy, Email: drreddy_2000@yahoo.com

\begin{abstract}
Introduction: Neonatal hyper bilirubinemia implies significant jaundice usually above $15 \mathrm{mg} / \mathrm{dl}$ or requiring treatment About $60-70 \%$ of all term newborns develop some degree of jaundice while in LBW babies it goes upto $80 \%$. Jaundice is more prevalent, severe and protracted in low birth weight babies, with more chance of producing neurological injury at lower levels of bilirubin. Methodology: This study is an attempt to compare the etiology and response to treatment modalities of hyperbilirubinemia in low birth weight and normal birth weight babies. About 150 babies including 50 low birth weight and 100 normal birth weight babies, who were admitted in NICU for neonatal hyperbilirubinemia were selected by purposive sampling and were further analyzed. The variables used for data analysis include number of children requiring phototherapy and exchange transfusion, age at initiation of phototherapy and exchange transfusion, pre phototherapy and pre exchange serum bilirubin, duration of phototherapy and rebound hyperbilirubinemia after phototherapy and exchange transfusion. Results: The most common etiological factors among low birth weight babies were prematurity, sepsis and ABO incompatibility, among normal birth weight babies were ABO incompatibility, sepsis, Rhincompatibility. In a large proportion of cases, etiology remained idiopathic. Among low birth weight babies Phototherapy was initiated early and at a lower bilirubin level. Duration of phototherapy was more, Rebound hyperbilirubinemia was higher and requirement of exchange transfusion was more. Conclusion: Hyperbilirubinemia due to incompatibilities prevailed though sepsis contributed a significant fraction among low birth weight babies. Significant hyperbilirubinemia developed earlier and persisted longer requiring prolonged phototherapy, exchange transfusion in low birth weight babies.
\end{abstract}

Key words: Exchange transfusion, Hyperbilirubinemia, Low birth weight, Normal birth weight, Phototherapy.

\section{Introduction}

Jaundice is the most common transitional finding in the newborn period. An elevation of serum bilirubin concentration $>2 \mathrm{mg} / \mathrm{dl}$ is found in virtually all newborns in first several days of life. It becomes clinically apparent at concentration $>5 \mathrm{mg} / \mathrm{dl}[1,2]$. Often it is entirely benign resolving by the end of the first week of life without treatment or sequalae.

About $60-70 \%$ of all term newborns develop some degree of jaundice while in low birth weight babies it goes upto $80 \%$ [3,4] among them 4-6\% develop significant neonatal hyperbilirubinemia. Over years, incidence has increased to $10-14 \%$, probably by

Manuscript received: $14^{\text {th }}$ September 2017

Reviewed: $24^{\text {th }}$ September 2017

Author Corrected: $30^{\text {th }}$ September 2017

Accepted for Publication: $6^{\text {th }}$ October 2017 increased suspicion and detection [5]. Neonatal hyperbilirubinemia implies significant jaundice usually above $15 \mathrm{mg} / \mathrm{dl}$ or more requiring treatment $[1,3]$. New born babies are more prone for hyperbilirubinemia due to increased bilirubin load on hepatocytes, decreased hepatic uptake from plasma, defective conjugation and delayed excretion [6].

Low birth weight babies are more prone for bilirubinassociated brain damage and other compli-cations of hyperbilirubinemia at lower levels of bilirubin compared to normal birth weight babies [7].

Because of immaturity of the physiological mechanisms, jaundice is more prevalent, severe and protracted in low birth weight babies, with more chance 
of producing neurological injury. Extreme hyperbilirubinemia leads to accumulation of free bilirubin, which crosses the blood-brain barrier and results in irreversible brain damage.

Kernicterus is a devastating, chronic disabling neurological disorder whose central nervous system (CNS) sequel reflect both a predilection of bilirubin toxicity for neurons (rather than glial cells) and the regional topography of bilirubin-induced neuronal injury that is characterized by prominent basal ganglia, cochlear, and oculomotor nuclei involvement $[8,9]$.

Michael Kaplan and Cathy Hammerman found incidence of kernicterus as $2-4 \%$ in severe hyperbilirubinemia [10]. Deanne Wilson Costello in his study of very low birth weight babies identified neonatal hyperbilirubinemia as a leading cause of cerebral palsy [11].

Until now, no consensus has been reached regarding the criteria to start phototherapy and exchange transfusion, especially in low birth weight babies though some guidelines are present for term and near term babies.

This study is an attempt to determine the etiology and response to treatment modalities of hyperbilirubinemia with an attempt to compare the same between babies of low birth weight and normal birth weight babies.

\section{Patients and Methods}

Study design: Prospective cohort study.

Place of study: Department of Pediatrics, NRI Medical College Hospital.

Period of study: January 2015 to June 2016.

Data source: 3268 babies delivered in NRI Medical College hospital during the time period between January 2015 and June 2016 were observed for the development of hyperbilirubinemia.

Study size: Among the 337 babies who developed significant hyperbilirubinemia, 150 babies, including 50 low birth weight babies and 100 babies of normal birth weight were selected by purposive sampling and were further analyzed.
Inclusion Criteria: Babies delivered in NRI Medical College hospital and developing significant hyperbilirubinemia, irrespective of the gestational age, over a period of 18 months.

\section{Exclusion Criteria}

- Where informed consent of parent/guardian was not obtained.

- In whom, necessary investigations could not be done or treatment could not be given due to any reason.

- Babies born and/ or treated outside.

For all babies receiving phototherapy, serum bilirubin was monitored every 24 hours till $24 \mathrm{hrs}$ after stopping phototherapy and for babies undergoing exchange transfusion, after $24 \mathrm{hrs}$ and 48 hours following the procedure, till serum bilirubin normalized.

Haemogram including reticulocyte count, blood group, DCT, septic screen and other relevant investigations were done as indicated to identify the etiology and severity of hyperbilirubinemia.

The serum bilirubin was assayed by the Diazo method of Pearlman and Lee.

Data analysis: The various etiological factors identified were analyzed with respect to the severity, prevalence and need for phototherapy and exchange transfusion.

These data in normal and low birth weight babies were compared and statistical significance analyzed wherever indicated using Student's' test.

Where ever necessary relevant statistics like Chi square test was used. P value $<0.05$ is set to be significant.

Quantitative variables: The variables used for data analysis include number of children requiring phototherapy and exchange transfusion, age at initiation of phototherapy and exchange transfusion, pre phototherapy and pre exchange serum bilirubin, duration of phototherapy and rebound hyperbilirubinemia after phototherapy and exchange transfusion.

\section{Results}

Table shows that the most common etiological factors noted among low birth weight babies were prematurity (58\%), Sepsis (22\%) and ABO incompatibility (16\%), while among babies of normal birth weight were ABO incompatibility $(27 \%)$, Sepsis (10\%) and Rh incompatibility (7\%). In a large proportion of cases, etiology could not be found out. 
Table- 1: Causes of NNH.

\begin{tabular}{|c|c|c|c|c|c|c|c|c|c|}
\hline & 疍 & $\frac{3}{3}$ & 色 & 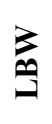 & & 党 & & 胥 & \\
\hline & Z & $\ddot{z}$ & $\stackrel{\circ}{z}$ & $\ddot{Z}$ & o & $\ddot{z}$ & 浂 & $\stackrel{0}{z}$ & 党 \\
\hline ABO incompatibility & 0 & 2 & 6 & 8 & 16 & 27 & 27 & 35 & 23.33 \\
\hline $\mathrm{Rh}$ incompatibility & 0 & 0 & 2 & 2 & 4 & 9 & 9 & 11 & 7.33 \\
\hline Minor incompatibility & 0 & 0 & 0 & 0 & 0 & 2 & 2 & 2 & 1.3 \\
\hline Sepsis & 2 & 4 & 5 & 11 & 22 & 10 & 10 & 21 & 14 \\
\hline Cephalohematoma & 0 & 0 & 0 & 0 & 0 & 9 & 9 & 9 & 6 \\
\hline Polycythaemia & 0 & 0 & 2 & 2 & 4 & 0 & 0 & 2 & 1.3 \\
\hline $\begin{array}{l}\text { Intraventricular } \\
\text { haemorrhage }\end{array}$ & 1 & 1 & 0 & 2 & 4 & 0 & 0 & 2 & 1.3 \\
\hline Downs syndrome & 0 & 0 & 0 & 0 & 0 & 2 & 2 & 2 & 1.3 \\
\hline Preterm & 5 & 16 & 8 & 29 & 58 & 0 & 0 & 29 & 19.33 \\
\hline Idiopathic & 0 & 0 & 10 & 10 & 20 & 41 & 41 & 51 & 33.33 \\
\hline Total & 5 & 16 & 29 & 50 & 100 & 100 & 100 & 150 & 100 \\
\hline
\end{tabular}

Table-2: Age of initiation of phototherapy.

\begin{tabular}{|c|c|c|c|c|c|c|c|c|}
\hline & \multicolumn{4}{|c|}{ LBW } & \multicolumn{4}{|c|}{ NBW } \\
\hline & $\stackrel{5}{\frac{\pi}{6}}$ & 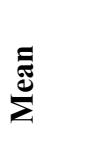 & 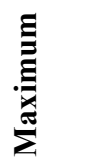 & 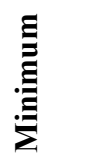 & $\stackrel{\frac{5}{6}}{\stackrel{\pi}{6}}$ & $\sum_{\Sigma}^{\Xi}$ & 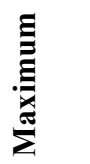 & 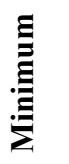 \\
\hline ABO incompatibility & 8 & 69.12 & 76 & 46 & 27 & 32 & 76 & 13 \\
\hline Rh incompatibility & 2 & 1 & 1 & 1 & 9 & 6.5 & 56 & 1 \\
\hline Minor incompatibility & $\mathbf{0}$ & NA & NA & NA & 2 & $\mathbf{5 0 . 5 0}$ & 76 & 25 \\
\hline Sepsis & 11 & 71.36 & 98 & 6 & 19 & 104.8 & 148 & 76 \\
\hline Cephalohematoma & $\mathbf{0}$ & NA & NA & NA & 9 & 74.33 & 94 & 68 \\
\hline Polycythaemia & 2 & 76 & 76 & 76 & $\mathbf{0}$ & $\mathbf{N A}$ & $\mathbf{N A}$ & NA \\
\hline $\begin{array}{l}\text { Intraventricular } \\
\text { haemorrhage }\end{array}$ & 2 & 38 & 75 & 1 & $\mathbf{0}$ & NA & NA & NA \\
\hline Downs syndrome & $\mathbf{0}$ & NA & NA & NA & 2 & 85.50 & 95 & 76 \\
\hline Preterm & 15 & 92.73 & 121 & 10 & $\mathbf{0}$ & NA & NA & NA \\
\hline Idiopathic & 10 & 95.1 & 116 & 70 & 41 & 87.1 & 116 & 68 \\
\hline Total & 50 & 63.33 & & & 100 & 67.25 & & \\
\hline
\end{tabular}

Table shows that phototherapy was initiated early in low birth weight babies (mean=63.33hours) compared to normal birth weight babies (mean $=67.25$ hours) 
Original Research Article

Table- 3: Pre phototherapy serum bilirubin

\begin{tabular}{|c|c|c|c|c|c|c|c|c|}
\hline & \multicolumn{4}{|c|}{ LBW } & \multicolumn{4}{|c|}{ NBW } \\
\hline & Total & Mean & Min & Max & Total & Mean & Min & Max \\
\hline ABO incompatibility & 8 & 16.29 & 15.7 & 21.3 & 27 & 15.46 & 14.1 & 20.4 \\
\hline $\mathrm{Rh}$ incompatibility & 2 & 4.45 & 3.85 & 5.1 & 9 & 4.3 & 3.6 & 5.2 \\
\hline Minor incompatibility & $\mathbf{0}$ & NA & NA & NA & 2 & 18.25 & 15.2 & 21.3 \\
\hline Sepsis & 11 & 11.67 & 2.8 & 16.3 & 10 & 17.17 & 16.2 & 18.1 \\
\hline Cephalohematoma & $\mathbf{0}$ & NA & NA & NA & 9 & 18.62 & 16.2 & 22.8 \\
\hline Polycythaemia & 2 & 15.2 & 14.2 & 16.2 & $\mathbf{0}$ & NA & NA & NA \\
\hline $\begin{array}{l}\text { Intraventricular } \\
\text { haemorrhage }\end{array}$ & 2 & 6.75 & 3.4 & 10.1 & $\mathbf{0}$ & NA & NA & NA \\
\hline Downs syndrome & $\mathbf{0}$ & NA & NA & NA & 2 & 16.95 & 15.8 & 18.1 \\
\hline Preterm & 15 & 11.94 & 2.4 & 16.3 & 0 & NA & NA & NA \\
\hline Idiopathic & 10 & 16.1 & 14.5 & 18.9 & 41 & 16.61 & 15.2 & 19.6 \\
\hline Total & 50 & 13.15 & & & 100 & 16.45 & & \\
\hline
\end{tabular}

Table shows that phototherapy was initiated at a lower bilirubin level in low birth weight babies $(\mathrm{mean}=13.15 \mathrm{mg} / \mathrm{dl})$ compared to babies of normal birth weight (mean=16.45 mg/dl)

Table-4: Duration of phototherapy.

\begin{tabular}{|c|c|c|c|c|c|c|c|c|}
\hline & \multicolumn{4}{|c|}{ LBW } & \multicolumn{4}{|c|}{ NBW } \\
\hline & $\begin{array}{c}\text { Total } \\
\text { No }\end{array}$ & $\begin{array}{c}\text { Mean } \\
(\text { hrs) }\end{array}$ & $\begin{array}{l}\text { Max } \\
\text { (hrs) }\end{array}$ & $\begin{array}{l}\text { Min } \\
\text { (hrs) }\end{array}$ & $\begin{array}{c}\text { Total } \\
\text { No }\end{array}$ & $\begin{array}{c}\text { Mean } \\
\text { (hrs) }\end{array}$ & $\begin{array}{l}\text { Max } \\
\text { (hrs) }\end{array}$ & $\begin{array}{l}\text { Min } \\
\text { (hrs) }\end{array}$ \\
\hline ABO incompatibility & 8 & 84 & 45 & 116 & 27 & 59.19 & 44 & 92 \\
\hline Rh incompatibility & 2 & 69.5 & 69 & 70 & 9 & 75.86 & 68 & 93 \\
\hline Minor incompatibility & $\mathbf{0}$ & $\mathbf{N A}$ & NA & NA & 2 & 82 & 70 & 94 \\
\hline Sepsis & 11 & 95 & 68 & 119 & 19 & 41.86 & 21 & 70 \\
\hline Cephalohematoma & $\mathbf{0}$ & NA & NA & NA & 9 & 61.89 & 44 & 72 \\
\hline Polycythaemia & 2 & 57.5 & 46 & 69 & $\mathbf{0}$ & NA & NA & NA \\
\hline $\begin{array}{l}\text { Intra ventricular } \\
\text { haemorrhage }\end{array}$ & 2 & 130.5 & 94 & 167 & $\mathbf{0}$ & NA & NA & NA \\
\hline Downs syndrome & $\mathbf{0}$ & $\mathbf{N A}$ & NA & NA & 2 & 32.5 & 21 & 44 \\
\hline Preterm & 15 & 76.8 & 45 & 117 & $\mathbf{0}$ & NA & NA & NA \\
\hline Idiopathic & 10 & 45.75 & 20 & 95 & 41 & 33.95 & 20 & 71 \\
\hline Total & 50 & 76.24 & & & 100 & 47.39 & & \\
\hline
\end{tabular}

Table shows that low birth weight babies required prolonged phototherapy 76.24 hours than normal birth weight babies 47.39 hours. 
Table- 5: Rebound hyperbilirubinemia

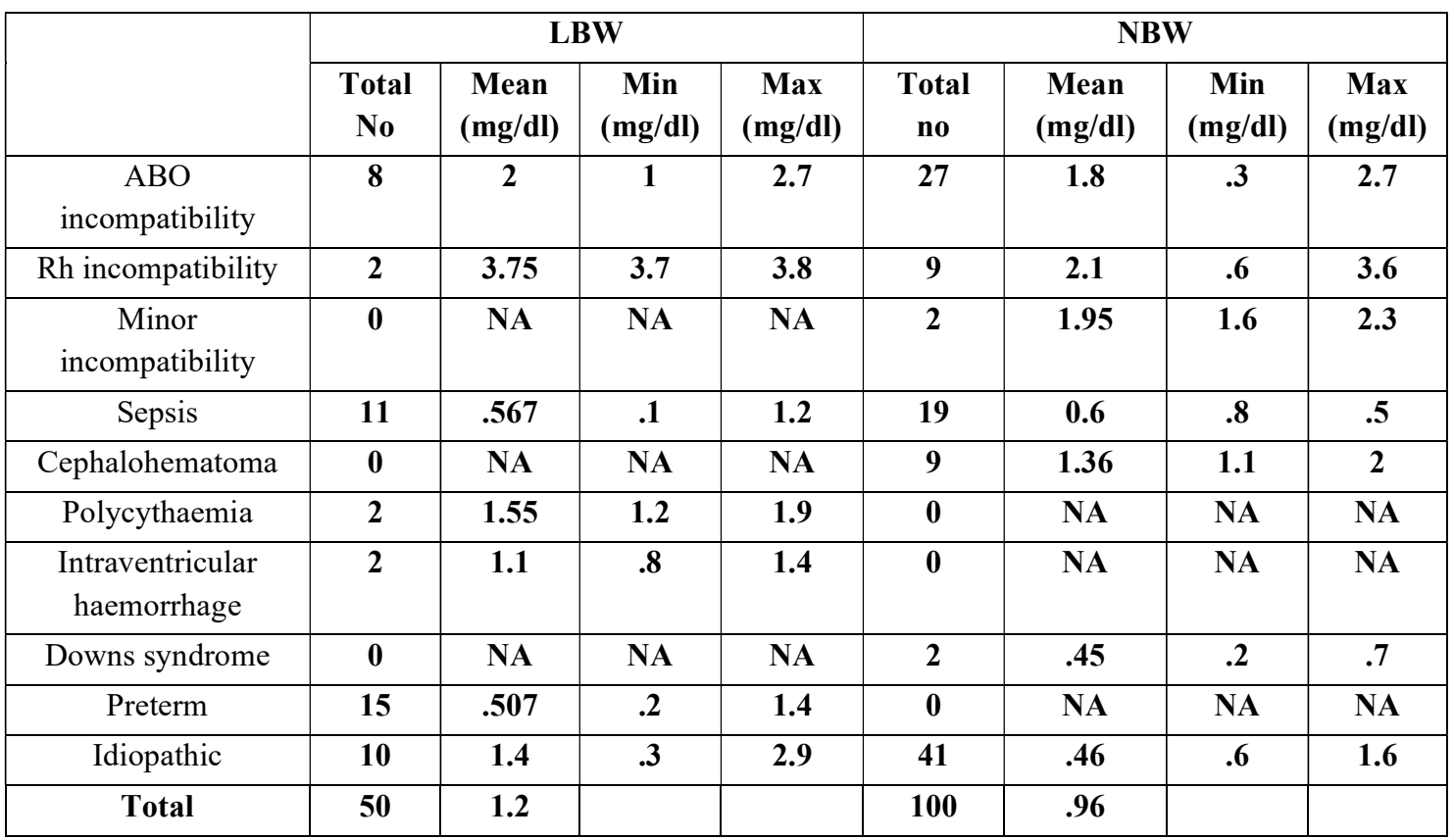

Table shows that rebound hyperbilirubinemia was more in low birth weightbabies (mean=1.2 $\mathrm{mg} / \mathrm{dl}$ ) than normal birth weight babies (mean=0.96 mg/dl).

Table- 6: Efficacy of phototherapy

\begin{tabular}{|c|c|c|}
\hline & NBW(100) & LBW(50) \\
\hline Pre phototherapy serum bilirubin (mg/dl) & 16.45 & 13.15 \\
\hline Post phototherapy serum bilirubin (mg/dl) & 13.25 & 9.4 \\
\hline Duration of phototherapy in hours & 47.39 & 76.24 \\
\hline Rate of decrease in bilirubin per hour & .07 & .05 \\
\hline \% of requirement of exchange transfusion & 3 & 4 \\
\hline Post phototherapy rebound (mg/dl) & .96 & 1.2 \\
\hline
\end{tabular}

Table summarizes the efficacy of phototherapy as assessed by the rate of decrease in serum bilirubin per hour, requirement of exchange transfusion and post phototherapy rebound.

Efficacy of phototherapy.

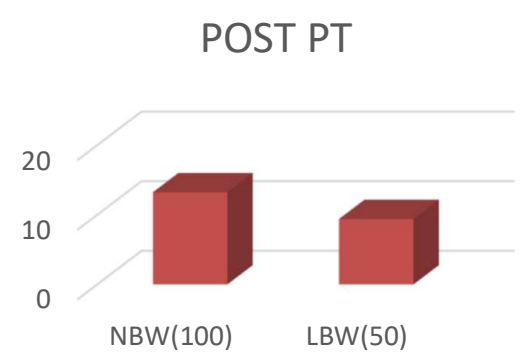

POST PT

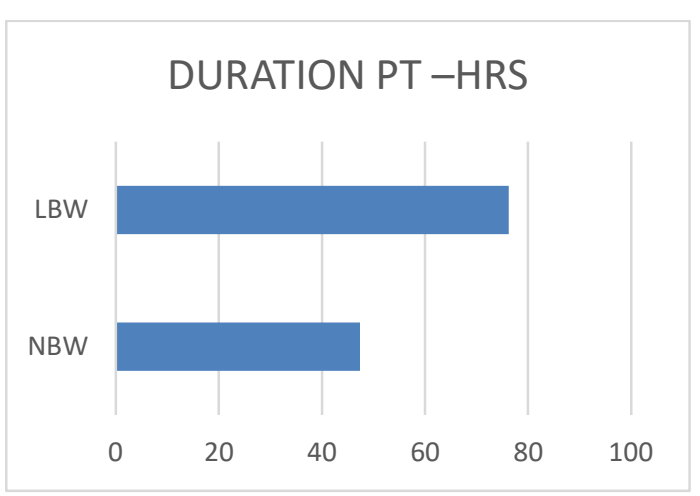

Fig compares the decrease in serum bilirubin, post phototherapy rebound and duration of phototherapy to assess the efficacy of phototherapy. 
Table-7: Exchange transfusion.

\begin{tabular}{|c|c|c|c|}
\hline & NBW (100) & LBW (50) & TOTAL (150) \\
\hline Rh incompatibility & 2 & 1 & 3 \\
\hline Sepsis & 1 & 0 & 1 \\
\hline Idiopathic & 0 & 2 & 5 \\
\hline Total & 3 & $4 \%$ & $3.33 \%$ \\
\hline
\end{tabular}

Table shows that Exchange transfusion requirement is more for low birth weight babies compared to normal birth weight babies.

Table- 8: Age of significant exchange transfusion

\begin{tabular}{|c|c|c|c|c|}
\hline & Number & Mean (hrs) & Maximum (hrs) & Minimum (hrs) \\
\hline Rh incompatibility & 3 & 11 & 14 & 7 \\
\hline Idiopathic & 1 & 25 & NA & NA \\
\hline Sepsis & 1 & 73 & NA & NA \\
\hline LBW & 2 & 19 & 73 & 12 \\
\hline NBW & 3 & 33 & 73 & 7 \\
\hline Total & 5 & & 25 & 7 \\
\hline
\end{tabular}

Table show that age of significant exchange is least for Rh incompatibility and low birth weight babies required exchange transfusion early.

Table- 9: Pre-exchange transfusion bilirubin

\begin{tabular}{|c|c|c|c|c|}
\hline & No & Mean $(\mathrm{mg} / \mathrm{dl})$ & Maximum (mg/dl & Minimum (mg/dl) \\
\hline Rh incompatibility & 3 & 15.33 & 16.9 & 14.1 \\
\hline Idiopathic & 1 & 22.4 & 22.4 & 22.4 \\
\hline Sepsis & 1 & 29 & 29 & 29 \\
\hline LBW & 2 & 19.65 & 22.4 & 16.9 \\
\hline NBW & 3 & 16.43 & 20.2 & 14.1 \\
\hline Total & 5 & & 29 & 7 \\
\hline
\end{tabular}

Table shows that Pre exchange bilirubin levels are more for sepsis,more in low birth weight babies.

Table-10: Rebound hyperbilirubinemia after exchange

\begin{tabular}{|c|c|c|c|c|}
\hline & No & Mean (mg/dl) & Maximum (mg/dl) & Minimum (mg/dl) \\
\hline Rh incompatibility & 3 & 5.13 & 6 & 4.2 \\
\hline Idiopathic & 1 & 4 & 4 & 4 \\
\hline Sepsis & 1 & 3.8 & 3.8 & 3.8 \\
\hline LBW & 2 & 5.6 & 6 & 5.2 \\
\hline NBW & 3 & 5 & 6 & 3.8 \\
\hline Total & 5 & & 6 & \\
\hline
\end{tabular}

Table shows that rebound is more in low birth weight babies and in Rh incompatibility. 


\section{Discussion}

This study attempted to determine the etiology, course and response to treatment of hyperbilirubinemia in newborn babies, with a comparison of the same with respect to their birth weight.

In our study, the most common etiological factors noted among all weight categories were $\mathrm{ABO}$ incompatibility $(23.33 \%)$ followed by preterm $(10 \%)$ and sepsis $(14 \%)$. Among low birth weight babies the most common were prematurity $(58 \%)$, sepsis $(22 \%)$ and $\mathrm{ABO}$ incompatibility (16\%), while among normal birth weight babies the most common factors were $\mathrm{ABO}$ incompatibility (27\%), sepsis (10\%), Rh incompatibility $(9 \%)$. In a large proportion of cases, etiology remained idiopathic (33.33\%). Sgro M [4] detected the commonest causes as idiopathic $(34.4 \%)$, prematurity (16.7\%) and ABO incompatibility (14.3\%). NarangA [5] detected the most common etiological factors as idiopathic (57.8\%) and sepsis (17.4\%). Tyker F [12]had similar results.

Our study found that phototherapy was initiated early in NBW babies (mean $=63.33$ hours) when compared to LBW babies (mean $=67.25$ hours). In either groups, babies with $\mathrm{Rh}$ incompatibility were the first to be started on phototherapy (mean $=1$ hour for low birth weight babies, $6.5 \mathrm{hrs}$ for normal birth weight babies), followed byIVH, ABO incompatibility in low birth weight babies and Minor group incompatibility, ABO incompatibility in normal birth weight babies. Babies whose cause of hyper bilirubinemia remained idiopathic (mean=95.1 hours) were the last to start on phototherapy among low birth weight babies, while among normal birth weight babies those with sepsis (mean $=104.8$ hours) were the last. Martin TC [13], Bertini G [14] found similar results.

In our study normal birth weight babies were noticed to have a higher pre-phototherapy bilirubin(mean $=16.45$ $\mathrm{mg} / \mathrm{dl}$ as compared to low birth weight babies (mean= $13.15 \mathrm{mg} / \mathrm{dl}$ ). Babies with $\mathrm{Rh}$ incompatibility had the least pre-phototherapy bilirubin (mean $=4.45 \mathrm{mg} / \mathrm{dl}$ in low birth weight and $4.30 \mathrm{mg} / \mathrm{dl}$ in normal birth weight babies) probably because intervention was at the earliest.

The highest pre-phototherapy bilirubin was for $\mathrm{ABO}$ incompatibility among low birth weight babies $(16.29 \mathrm{mg} / \mathrm{dl})$ and for Cephalohematoma among normal birth weight babies $(18.62 \mathrm{mg} / \mathrm{dl})$. Narang. A [5] in his analysis of 551 cases noticed that pre-phototherapy bilirubin was higher in babies of normal birth weight (17.82 $\mathrm{mg} / \mathrm{dl})$ compared to low birth weight babies (14.13 $\mathrm{mg} / \mathrm{dl})$. The present study observed that phototherapy was given for a longer duration in low birth weight babies (mean $=76.08$ hours) which was much more than that for normal birth weight babies (mean $=47.39$ hours). Phototherapy was given for the maximum duration for preterm babies with IVH in the low birth weight group (130.5 hours) and in normal birth weight babies, minor incompatibilities (82 hours). Phototherapy was given for the least duration for babies whose etiology was idiopathic in low birth weight group (45.67 hours) and for babies with Down syndrome in the normal birth weight group (32.5 hours). Narang A [5] and others in his analysis of 551 cases noticed that the duration of phototherapy was more in low birth weight babies (67.31 hours) compared to babies of normal birth weight (50.14 hours). Also he found that duration of phototherapy was more for babies with prematurity and sepsis.

Rebound hyperbilirubinemia was higher in low birth weight babies (mean $=1.2 \mathrm{mg} / \mathrm{dl}$ ) when compared to normal birth weight babies (mean $=.96 \mathrm{mg} / \mathrm{dl}$ ). Rebound hyperbilirubinemia was maximum for was $\mathrm{Rh}$ incompatibility in either weight groups (mean= 3.75 $\mathrm{mg} / \mathrm{dl}$ for low birth weight babies and $2.1 \mathrm{mg} / \mathrm{dl}$ for normal birth weight babies). Maisels $\mathrm{MJ}$ et al [15] reported a mean rebound of $1.3 \mathrm{mg} / \mathrm{dl}$ at a mean post phototherapy bilirubin of $10.4 \mathrm{mg} / \mathrm{dl}$ and $0.27 \mathrm{mg} / \mathrm{dl}$ when the mean post phototherapy bilirubin was 12.3 $\mathrm{mg} / \mathrm{dl}$.

Exchange transfusion was performed mainly for incompatibilities. About $27.27 \%$ of all $\mathrm{Rh}$ incompatibilities required exchange transfusions. Among exchange transfusions in $60 \%$ cases etiology is $\mathrm{Rh}$ incompatibility. Exchange transfusion was done at the earliest in Rh incompatibility (mean $=11$ hours) and was quite late in Sepsis (mean=73 hours) in our study.

Pre-exchange transfusion bilirubin was least in $\mathrm{Rh}$ incompatibility $($ mean $=15.33 \mathrm{mg} / \mathrm{dl}$ ) and maximum in sepsis $($ mean $=29 \mathrm{mg} / \mathrm{dl})$. This is probably because exchange transfusion is done at a much younger age in $\mathrm{Rh}$ incompatibility before very high bilirubin levels are reached.The rebound hyperbilirubinemia after exchange transfusion in our study was maximum for $\mathrm{Rh}$ incompatibility $($ mean $=5.13 \mathrm{mg} / \mathrm{dl})$ and minimum in Sepsis $($ mean $=3.8 \mathrm{mg} / \mathrm{dl}$ ). Abu Ekenstein [16] have similar results. 


\section{Conclusion}

Hyperbilirubinemia due to incompatibilities prevailed though sepsis contributed a significant fraction among low birth weight babies and cephalohematoma among babies of normal birth weight. Significant hyperbilirubinemia developed earlier and persisted longer requiring prolonged phototherapy in low birth weight babies. Requirement of exchange transfusion is also more in low birth weight babies.

\section{Abbreviations}

ELBW: Extremely low birth weight, VLBW: Very low birth weight, LBW: Low birth weight, NBW: Normal birth weight, IVH: Intra ventricular hemorrhage

Funding: Nil, Conflict of interest: None initiated, Perission from IRB: Yes

\section{References}

1. Cloherty JP, Eichenwald EC, Stark AR, editors. Manual of neonatal care. Lippincott Williams \& Wilkins; 2008.

2. Gomella T, Cunningham M. Neonatology 7th Edition. McGraw-Hill Prof Med/Tech; 2013 Jul 21.

3. Dennery PA, Seidman DS, Stevenson DK. Neonatal hyperbilirubinemia. New England Journal of Medicine. 2001 Feb 22;344(8):581-90.

4. Sgro M, Campbell D, Shah V. Incidence and causes of severe neonatal hyperbilirubinemia in Canada. Canadian Medical Association Journal. 2006 Sep 12; 175 (6):587-90.

5. Narang A, Kumar P, Kumar R. Neonatal jaundice in very low birth weight babies. Indian journal of pediatrics. 2001 Apr 1;68(4):307-9.

6. Watchko JF, Maisels MJ. Jaundice in low birthweight infants: pathobiology and outcome. Archives of Disease in Childhood-Fetal and Neonatal Edition. 2003 Nov 1;88(6):F455-8.

7. Maisels MJ, Watchko JF. Treatment of jaundice in low birth weight infants. Archives of Disease in
Childhood-Fetal and Neonatal Edition. 2003 Nov 1; 88 (6) : F459-63.

8. Watchko JF. Kernicterus and the molecular mechanisms of bilirubin-induced CNS injury in newborns. Neuromolecular medicine. 2006 Dec 1;8 (4): 513-29.

9. Shapiro SM, Bhutani VK, Johnson L. Hyperbilirubinemia and kernicterus. Clinics in perinatology. 2006 Jun 30; 33(2):387-410.

10. Kaplan M, Hammerman C. Glucose-6-phosphate dehydrogenase deficiency: a hidden risk for kernicterus. In Seminars in perinatology 2004 Oct 31 (Vol. 28, No. 5, pp. 356-364). WB Saunders.

11. Wilson-Costello D. Risk factors for neurologic impairment among very low-birth-weight infants. InSeminars in pediatric neurology 2001 Jun 30 (Vol. 8, No. 2, pp. 120-126). WB Saunders.

12. Tiker F, Tarcan A, Kilicdag H, Gürakan B. Early onset conjugated hyperbilirubinemia in newborn infants. The Indian Journal of Pediatrics. 2006 May 1; 73 (5):409-12.

13. Martin TC, Shea M, Alexander D, Bradbury L, Lovell-Roberts L, Francis V. Did exclusive breastfeeding and early discharge lead to excessive bilirubin levels in newborns in Antigua and Barbuda?. The West Indian medical journal. 2002 Jun;51(2):84-8.

14. Bertini G, Dani C, Tronchin M, Rubaltelli FF. Is breastfeeding really favoring early neonatal jaundice? Pediatrics. 2001 Mar 1;107(3):e41-.

15. Maisels MJ, Kring E. Rebound in serum bilirubin level following intensive phototherapy. Archives of pediatrics \& adolescent medicine. 2002 Jul 1; 156 (7): 669-72.

16. Abu-Ekteish F, Daoud A, Rimawi H, Kakish K, Abu-Heija A. Neonatal exchange transfusion: a Jordanian experience. Annals of Tropical Paediatrics: International Child Health. 2000 Mar 1;20 (1):57-60.

\section{How to cite this article?}

V VV N S. Ravi Sankar, Reddy L. N, Vijayalakshmi B, Sravanthi N. L. Study of hyper bilirubinemia in Low Birth Weight (LBW) and Normal Birth Weight (NBW) babies. Int J Pediatr Res. 2018; 5 (4): 222-229.doi:10. 17511/ijpr.2018.i04.11. 